\title{
Religion and Secularisation in the Czech Republic
}

\author{
DUŠAN LUŽNY̌́* \\ Institute for the Study of Religions, Faculty of Arts at Masaryk University, Brno \\ JOLANA NAVRÁTILOVÁ* \\ Faculty of Social Studies of Masaryk University, Brno
}

\begin{abstract}
Using an analysis of data from the European Values Study of 1991 and 1999 (together with data from the International Social Survey Programme 1998 Religion from 1999, and data from other public opinion surveys), this article tries to suggest the scope of secularisation in the present Czech population. It documents how the process of structural differentiation leads to the declining significance of institutionalised religiousness and privatisation of religion, as well as to a growing belief among Czech citizens that it is inappropriate for churches to try to influence politics or the economy. The article also raises the issues of the number of believers and the forms of their beliefs. One of the results of our analysis is the finding that the Czech Republic might be the most secularised country in Europe at the present time.
\end{abstract}

Czech Sociological Review, 2001, Vol. 9 (No. 1: 85-98)

If we look at the theoretical reflections of the position of religion and religious values in Western Europe since World War II, we find that the most discussed themes have been the declining significance of tradition and secularisation. Religious institutions have lost their all-pervading influence over the lives of the majorities in these countries, the frequency of religious practice has dropped, traditional churches and denominations have declined in number and in their public impact, and hitherto common beliefs, rooted in religious (in this region Christian) worldview are also fading. This structural trend cannot be counterpoised even by a renewal of religious faith in small non-traditional communities. It is true that secularisation is a self-limiting process and that it supports religious innovation and import - i.e. the emergence and further existence of non-traditional sects and cults [Stark and Bainbridge 1996: 279-313]. However, at the same time it is equally true that these new religious organisations are not gaining economic, political and cultural significance [Wilson 1979, Hammond and Shibley 1993].

The situation in countries with communist governments was of course different given the fact that the declining significance of a long-term tradition of religious values and secularisation had been deliberately supported. Before 1989, all public functions of religion were suppressed on purpose, and religion itself was atheistically interpreted and devaluated as a mere 'anachronism'. A large range of priests were imprisoned or executed, church orders were abolished, church property was confiscated and the life of religious organisations was submitted to state surveillance. Religious life was pushed out of the public sphere into the private sphere of individual citizens or illegal structures. These practices naturally reaped results in the decline of religious beliefs and attitudes. Thus, according to some authors the development of the position of religion in post-communist

*) Direct all correspondence to: PhDr. Dušan Lužný, Dr., Ústav religionistiky, Filozofická fakulta MU, 66088 Brno, Czech Republic, e-mail luzny@phil.muni.cz 
countries cannot be viewed only through the narrow optics of secularisation but must always be completed by taking into account its peculiarities [see e.g. Tomka 1988].

Also specific is the situation after the fall of the regimes in Eastern Europe, which was often accompanied by a certain religious revival. In the Czech Republic, after the November 'velvet revolution', religion again became a firm part of public life and new expectations arose concerning the new place of religion in society. These expectations played themselves out on two levels. The first one was directed to the established traditional churches which have not, however, used the situation properly. They focused on their internal problems and in the following years reduced religious questions mainly to the issues of restitution of church property, of internal 'purification' from the 'cooperation' with the communist regime, or of 'purification' from 'parallel' church structures (the discussion on the legitimacy of the so-called hidden church). During these discussions, traditional churches did not represent themselves as structures capable of dynamic reactions to the rapidly changing conditions of a transforming Czech society.

The second level of expectations was not connected with the traditional form of institutionalised religiousness but rather, in the first years after November 1989, with a search for a kind of all-human and universalistic religion, the religion of tolerance and humanism. People did not seek any pre-defined religion but allowed themselves to be influenced by individual aspects of various religions, finding positive features in all religious trends. This side of religious expectation corresponded to the general atmosphere of the Czech (then Czecho-Slovak) society, which was marked by its openness, and the search manifested itself in many branches of life - from politics through economics to religion. Further development, however, confirmed the victory of utilitarian pragmatism that emphasised economically conceived material values. Thus, both levels of religious expectations from the beginning of the 1990s were not fulfilled, and the public significance of religion began to weaken.

This implies a certain return to the secularisation trends from the former era. The biggest impact on this development can be ascribed to the three following factors: a) the anti-Catholic attitudes of the Czech public (their influence can be traced back to Hussite movements, through the national revivalist movement and the resistance against the Hapsburg monarchy, to communist atheism); b) secularisation tendencies given by the structural differentiation of modern societies; c) the atheistic propaganda of the communist regime.

\section{The Concept of Secularisation}

Despite the fact that the post-communist countries have specific features, they cannot be excluded from the European region. The region can be characterised - as opposed to most other regions in the present world - by a considerable decline of religions, often interpreted within the concept of modernisation. According to classical sociological theories, the modernisation process is closely connected with the changing place of religion in the life of society. Among the key features of modernisation is the process of structural differentiation, in which the various spheres of society (such as politics, economics, law, family, religion etc.) become structurally separated and formulate rules of their own which they then follow. These rules are not transferable to other spheres.

Secularisation can be defined as a process in which religious institutions, action and consciousness lose their social significance. This process also includes the loss of 
property and the political power of religious subjects, a shift from religious control to secular control, a decrease in the amount of time, energy and other means that people devote to supernatural things, and the replacement of religious commandments by demands corresponding to strictly rational, empirical and technical criteria [Wilson 1992: 149]. However, secularisation is not a process resulting in the decline or even demise of religion. It affects mainly traditional forms of religion and in particular those forms that are connected with a strongly institutionalised religiousness typified by churches. Secularisation can thus be viewed as a continuing decline of the power of religious organisations, which has another aspect - the growing popularity of non-church religiousness and non-traditional religious groups, a religious revival and experimentation [Stark and Bainbridge 1996: 293, 304].

This process is the result of a strong specialisation of religion that has limited religious life only to forms that take place in a religious organisation and have an institutional character. Official religious life was closed within churches, and thus separated from other spheres of society. The counter-reaction then consisted in the development of unofficial, strongly private, 'invisible' religiousness [Luckmann 1967].

This article is directed at the two accompanying phenomena of secularisation that have already been mentioned: the decline in the importance and power of religious organisations, and the privatisation of religion. We will try to address the question as to whether after 1989 the Czech Republic witnessed a process of unchurching and privatisation, by using empirical data gained from the two European Values Studies (EVS) carried out in 1991 and 1999, and by comparing and complementing them with the data of The International Social Survey Programme 1998 - Religion (ISSP) also from 1999 [see also Hamplová 2000], as well as data of the Institute for the Research of Public Opinion (IVVM).

Our interest in this article is focused on one fundamental question: Is it possible by means of using the mentioned surveys to determine the form and scope of secularisation in the Czech Republic? For this purpose, we understand secularisation as a process with two basic levels - institutional and behavioural. ${ }^{1}$ Secularisation at the institutional level means structural differentiation (i.e. the structural emancipation of social spheres in modern society, which is - in societies of the Western type - connected to the process of the decline of the societal significance of traditional churches), and at the behavioural level refers to the privatisation of religion.

The results presented in this text, rather than being an integrated empirically proved concept, are initial hypotheses that try to show possible changes in the religious life of Czech citizens. These hypotheses have to be empirically tested in further (both quantitative and qualitative) research.

\section{The Number of Believers, People with Denomination, Religious Practice}

As one of the most basic indicators of religiousness we can take the religious selfdeclaration of respondents, i.e. declaring oneself as a religious person or as belonging to a religious denomination (or confession), belief in the existence of God (or some other

1) Secularisation has also a third level, which is the rationalisation of consciousness - i.e. the growth of trust into rationalistic explanations of the world and 'de-enchantment' of the world. This level will be mentioned here only marginally. 
traditional beliefs) etc. Making a quick comparison, it is possible to claim that the Czech Republic is, according to these indicators, one of the most irreligious countries in Europe, along with the countries of former Eastern Germany, and with Estonia. In Western Europe, examples of the least religious countries could be Netherlands or Sweden. ${ }^{2}$ However, to render a more animated picture, it is necessary to describe the measured values more concretely and to investigate possible trends.

From a certain point of view it can be said that religiousness in the Czech Republic is growing. Independent of the practice connected to a given denomination, an entire $40.4 \%$ of respondents regard themselves as religious people (believers), ${ }^{3}$ while this number has increased a little when compared with the year 1991 (see Table 1).

Table 1. Respondent's sense of religiousness (in \%)

"Apart from the fact of whether you attend religious services or not, could you describe yourself as:"

\begin{tabular}{lrr} 
& 1991 & 1999 \\
\hline Believers & 37.4 & 40.4 \\
Non-believers & 47.4 & 45.4 \\
Atheists & 4.9 & 7.7 \\
do not know & 10.2 & 5.3 \\
no answer & 0.1 & 1.1 \\
\hline
\end{tabular}

Source: $\quad$ EVS 1991 and EVS 1999

Conversely, a slight decrease can be documented in the number of people claiming to belong to some denomination (church) - in 1999 this was 33.5\% of population, while in 1991 it was 39.4\%. Logically, there must have been a decrease in the number of Christians, since they form $97.5 \%$ of all people belonging to denominations (the RomanCatholic church itself counts for more than $84 \%$ of respondents from this group). Jan Spousta [1999: 74] documents a one-fifth decrease in the number of church members in our country on the basis of a cohort comparison of the age structure of people belonging to a denomination in 1991 and 1999. Although a kind of general religiousness has thus remained or has even grown, the religiousness measured by membership in denominations or by beliefs in concrete Christian dogmas seems to be declining.

Faith and denomination do not exactly overlap, which can also be supported by the fact that only $71 \%$ of people declaring themselves believers at the same time belong to some religious denomination. Before we come to explore the circumstances of this statement, it is necessary and useful to compare the groups of religious people with regard to their age structure. The tie between age and religious beliefs and attitudes is very strong as the demographic change of generations constitutes one of the most frequent causes of the decline (or transformation) of religiousness, mainly in its Christian and churchoriented forms. Equally, the data from the latest surveys in the Czech Republic confirm

2) If one compares the affirmative answers to the question about the belief in God (yes-no answer) from EVS 1999, the Czech Republic comes out as the least religious country of all, when we do not count former Eastern Germany [see also Štampach 1999: 66]

3) The Czech translation of this question uses the word 'believer' or 'believing person', not 'religious person', and therefore we shall use the former to respect the meaning difference these terms have in Czech. 
that religion - especially Christian denominations - is a matter for older people belonging to the generations born in the first half of this century. This is also visible from the finding that in the group of religious/believers (or, in the group of people belonging to some denomination, or group of people believing in God, etc.), the average age is approximately ten years higher than in the group of non-believers. There is also a higher percentage of women among the groups of religious people in the Czech Republic, which can only be partly explained by their prevalence in the higher age categories.

Let us compare the answers to the question of the respondent's sense of religiousness, (variants used: believer, non-believer, atheist, DK) laid out in EVS in 1991 and 1999. Among groups of the same age, we clearly see that as the oldest generation dies, the religiousness measured by this question is decreasing in the older age groups, since the successive generations lack that high percentage of believers (see Table 2). At the same time, this religiousness grows among younger generations, mainly among people under 30 years of age. From the comparison of the same cohorts, which can illustrate the development over the years since 1991, one can see that the percentage of believers increased in all age groups born after 1943. The numbers of respondents in all the cohorts being not very high, we cannot overestimate the explanatory value of this comparison.

Table 2. Sense of religiousness (percentage of believers) "Apart from the fact whether you attend religious services or not, could you describe yourself as:"

Comparison of same age groups 1991

1999

Development of the same cohorts 1991

1999

\begin{tabular}{lclccccr} 
Groups & believers & Groups & believers & Cohorts & believers & \multicolumn{2}{c}{ Cohorts believers } \\
\hline $18-25$ & 20.6 & $18-25$ & 32.6 & & & $18-25$ & 32.6 \\
$26-33$ & 22.2 & $26-33$ & 34.1 & $18-25$ & 20.6 & $26-33$ & 34.1 \\
$34-41$ & 24.3 & $34-41$ & 36.9 & $26-33$ & 22.2 & $34-41$ & 36.9 \\
$42-49$ & 39.7 & $42-49$ & 35.3 & $34-41$ & 24.3 & $42-49$ & 35.3 \\
$50-57$ & 60.0 & $50-57$ & 45.9 & $42-49$ & 39.7 & $50-57$ & 45.9 \\
$58-65$ & 62.8 & $58-65$ & 55.3 & $50-57$ & 60.0 & $58-65$ & 55.3 \\
$66+$ & 74.5 & $66+$ & 63.1 & $58-65$ & 62.8 & $66+$ & 63.1 \\
Total & 37.4 & Total & 40.4 & $66+$ & 74.5 & & \\
\hline
\end{tabular}

Source: $\quad$ EVS 1991 and EVS 1999.

Nonetheless, part of the future trends will probably be the demise of religious denomination, in our country massively corresponding to church membership and religiousness. An almost dramatic decline can be observed, if one takes into account the percentage of people belonging to some denomination in 1991 and 1999, among groups of people older than 42 years of age (see Table 3). On the one hand, the comparison of the same cohorts can illuminate the extent to which these low numbers result from the exchange of generations. However, at the same time, it confirms the general decline, since even the slightly growing number of people belonging to denominations among younger groups cannot counterbalance the high church religiousness of older generations. 
Table 3. Belong to a denomination at present time (yes-no answer) "Do you belong to any religious denomination?"

\begin{tabular}{llllllll}
\multicolumn{3}{c}{$\begin{array}{c}\text { Comparison of same age groups } \\
\text { 1991 }\end{array}$} & \multicolumn{2}{c}{ 1999 } & \multicolumn{2}{c}{ Development of the same cohorts } \\
Groups & YES & Groups & YES & Cohorts & YES & Cohorts & YES \\
\hline $18-25$ & 14.2 & $18-25$ & 19.5 & & & $18-25$ & 19.5 \\
$26-33$ & 20.1 & $26-33$ & 18.8 & $18-25$ & 14.2 & $26-33$ & 18.8 \\
$34-41$ & 21.5 & $34-41$ & 24.9 & $26-33$ & 20.1 & $34-41$ & 24.9 \\
$42-49$ & 43.9 & $42-49$ & 25.9 & $34-41$ & 21.5 & $42-49$ & 25.9 \\
$50-57$ & 58.8 & $50-57$ & 38.7 & $42-49$ & 43.9 & $50-57$ & 38.7 \\
$58-65$ & 62.1 & $58-65$ & 53.5 & $50-57$ & 58.8 & $58-65$ & 53.5 \\
$66+$ & 70.8 & $66+$ & 56.5 & $58-65$ & 62.1 & $66+$ & 56.5 \\
Total & 33.5 & Total & 39.4 & $66+$ & 70.8 & & \\
\hline
\end{tabular}

Source:

EVS 1991 and EVS 1999.

As far as this indicator is concerned, the Czech Republic once again emerges as the least religious country in Europe (according to EVS from the year 1999). The only region with a lower level of religiousness, measured by this question, is former Eastern Germany, where this number is only $34 \%$, and among the countries in Western Europe, the Netherlands coming close with its $45 \%$ of people with a denomination. Comparing this with other countries, in former Western Germany the number was approximately $86 \%$ (the number for the whole Germany is $60 \%$ ), in Austria 87\%, in Slovakia almost $77 \%$, and in Poland $96 \%$.

To complete the picture of self-declared religiousness and religious denomination, it is useful to present data stating the frequency (equally self-declared) of attendance at religious services. Although more than one-third of people claim to be believers (or claim to believe in God or belong to a religious denomination), only $11.5 \%$ of Czech citizens can be regarded as regular church-goers, attending services at least once a month. Those who go to church on a weekly basis count for less than $7 \%$. This percentage is naturally higher among older people - among people older than sixty years of age, $16 \%$ attend religious services at least once a week. Although these indicators also make the Czech Republic the least religious European country, the decline in the attendance of church and religious services does not correspond to the decline in the number of people belonging to religious denominations. Jan Spousta explains this fact by stating that the difference is caused by lukewarm church-members who do not claim their denomination any more [Spousta 1999: 77].

To answer the question of how many people tie their religiousness to practice and how many believers (or members of denominations) are not among the lukewarm ones, it is possible to look at the percentage of regular attendants at religious services in relevant groups. One discovers that the number of more or less regular church-goers is $28 \%$ in the group of believers and over $34 \%$ in the group of people with Christian denominations 4 (in 1991 , this was $30 \%$ of believers and $28.5 \%$ of Christians). The percentage of weekly

4) For illustration we choose Christian denominations, and not all, since the form of the question (in Czech: 'God's service') suits them best. Apart from this, people of Christian denominations comprise $97.5 \%$ of all people with denomination (in 1991, it was almost 99\%), and thus we shall use Christians in our comparisons. 
regular attendants is then approximately $17 \%$ of believers and one-fifth of the Christians. It can be stated at the same time that among Christians the percentage of weekly churchgoers is not declining (on the contrary, the lukewarm ones fall away). The lower frequency of attendance at religious services among self-declared believers might correspond to the decreasing number of people belonging to denominations in this group.

The description of religiousness cannot be concluded without taking into account the place of religion in society. We can at least look at the answers to the question in which the respondents had to express the importance of selected areas of society in their own lives. If we construct a hypothetical scale from the results of these answers, religion is at the very end of this scale of importance. (The order would be the following: first is family, then work, friends, leisure time, politics, and religion. In this succession, our republic does not differ from other countries - the only difference is the very low level of the importance of religion.) Religion was considered to be important in the lives of $19.4 \%$ of people, and unimportant in the lives of $79.2 \%$ (in 1991, the ratio was $26.5 \%$ to $72.3 \%$ ). At the same time there was a slight decrease in the number of people who considered it very important, and a remarkable increase in the number of those who considered it not important at all. This might be a reflection of the demise of the hopes and expectations that had been put into religion after November 1989.

Since 1991, the general trust in churches (or the church) decreased. Although churches score just immediately after the educational system (and before government, parliament and business), the prevailing attitude towards them is a lack of trust. Czech citizens also started to lose their initial opinion that churches are dealing with problems other than spiritual ones (such as moral, social or family problems) in people's lives. While in 1989, a whole range of people were sympathetic to church religiousness and regarded religion as an important part of social life, the following years - in which discussions on the restitution of church property also took place - have not confirmed this favourable trend. Church belongs among the institutions (after the Senate and the House of Representatives) in which people show the least trust (according to both value distributions and means in EVS 1999).

The methodologically problematic identification of religion in its church form is evident also from the results of research study ISSP 1998, carried out in 1999 . Only $9.4 \%$ of people in this survey clearly stated that they regard themselves as religious persons living according to church doctrines, while $28 \%$ admitted that they are religious in their own way ( $26.5 \%$ could not decide and $32.9 \%$ declared themselves as non-religious). The mentioned data indicate that only a relatively small part of believers take into account the official form of their religion, which might document a declining institutionalised (church) control over the content of religious belief. This fact can be explained by the changing situation of religion in a modern, functionally differentiated society, in which churches have lost their dominant position in questions of worldview interpretations, and institutionalised religion has become 'just' one societal sub-system among others. The results of this demonopolisation of religion are religious pluralism and its companion religious competition [Berger 1967: 137]. In the market contest of religious ideas, isolated and detraditionalised elements of various religions are offered in such a way that they can be individually consumed in privacy. Their hybridisation is an interrelated phenomenon. As a result, we have $16.5 \%$ of Czech Christians believing in reincarnation (EVS 1999), which is a concept foreign to the official doctrines of Christian churches. 
The situation in other countries is similar, when 'reincarnation is integrated into the belief system of 20 percent of practising Catholics in Belgium' [Dobbelaere 1993: 24].

\section{Form of Religiousness}

Self-declaration of faith or denomination, as well as the proclamation of ritual behaviour (religious practice) are of course not the only measures of human religiousness. It is equally relevant to ask about the form of belief and other views and attitudes that are (either traditionally or newly) connected with religiousness. These latter indicators, however, bear a close relationship to the former ones [Dobbelaere 1993: 21], and thus can serve as a useful complement.

As an introduction to the forms of beliefs, we would like to point to a couple of illustrative figures. While in 1991 more than $85 \%$ of the people who declared themselves as believers claimed to belong to some religious denomination, by 1999 their number decreased (as we noted earlier) to less than $71 \%$. The rest, $29 \%$ of believers, can hypothetically be considered (on the basis of their subjective view of themselves as believers) to represent some non-traditional religiousness without denomination. To complete this, we can add that, in 1991, only $81 \%$ of people of Christian denominations regarded themselves as believers, and in 1999 this ratio slightly increased to $85 \%$. This could correspond to the thesis according to which after the November revolution of 1989, many 'formal' Christians (i.e. people who derive their denomination from the act of being baptised) claimed their denomination but, later on, failed to claim it any more [see also Spousta 1999]. The groups of believers and Christians can be used when we want to document some shifts in religious views and attitudes.

Taking into account the predominance of Christianity in the European region, it becomes relevant to explore the opinions of the Czech population on the existence and image of God. The 1999 EVS survey (using a yes-no question) has shown that an entire one-third of respondents believe in the existence of God, while one-half does not believe, and around $15 \%$ of people cannot answer the question. A similar number of believers could be derived from the ISSP 1998 survey, according to which - answering another, more differentiated question - over 30\% claimed they believe in God (even if sometimes with doubts). These figures also do not differ very much from those acquired in the 1991 EVS survey. What changes is the form of God in which people believe (the image they have in mind. If we turn to EVS 1999 , only $18.5 \%$ of people who said they believed in God state in another question that they believe in a personal God, while more than twothirds of people from this group incline towards the existence of some spirit or life force. ${ }^{5}$ The following table is a good illustration of the growing complexity of contemporary religious life.

5) When interpreting this question as speaking about the 'form of God', there is a need for a certain caution. It does not state anything like this explicitly (the question is: "Which of the statements is closest to your beliefs?"), it only implies that the respondent is choosing a form of God. 
Table 4. Statement of respondent's belief (in \%)

"Which statement is closest to your belief?"

\begin{tabular}{lccccc} 
Group & $\begin{array}{c}\text { Existence } \\
\text { of personal } \\
\text { God }\end{array}$ & $\begin{array}{c}\text { Existence } \\
\text { of spirit or } \\
\text { life force }\end{array}$ & $\begin{array}{c}\text { Really do } \\
\text { not know } \\
\text { what to think }\end{array}$ & $\begin{array}{c}\text { I do not think } \\
\text { there is God or } \\
\text { any life force }\end{array}$ & $\begin{array}{c}\text { DK } \\
\text { or NA }\end{array}$ \\
\hline 1991 - all people & 11.0 & 35.8 & 25.4 & 22.4 & 5.2 \\
1991 - believers & 26.0 & 44.2 & 19.3 & 5.1 & 4.6 \\
1991 - Christians & 24.2 & 41.5 & 22.1 & 8.1 & 4.1 \\
1999 - all people & 6.3 & 48.5 & 20.2 & 21.5 & 3.5 \\
1999 - believers & 15.0 & 67.0 & 11.4 & 4.7 & 1.9 \\
1999 - Christians & 18.1 & 58.9 & 14.5 & 5.9 & 2.6 \\
1999 - believers in God & 18.5 & 68.7 & 9.0 & 2.5 & 1.6 \\
\hline
\end{tabular}

Source: $\quad$ EVS 1991 and EVS 1999.

We can see that only $6.3 \%$ of respondents (in 1991 it was $11 \%$ ) identify with the belief in the existence of a personal God. The ratio is, naturally, higher among believers or Christians (it is $15 \%$ and approximately $18 \%$, respectively). However, even among these groups, the belief in a personal God has declined since 1991 (at that time, this statement was chosen by $26 \%$ of believers and by approximately $24 \%$ of Christians). The remarkable weakness of this belief in our country can be confirmed by the data from other countries, where even within the whole set of respondents a much larger number of people identified with the belief in a personal God - it was $23.5 \%$ in the Netherlands, around $29 \%$ in Germany (with 36.7\% for former West Germany, and only 20.5\% for former East Germany), 31\% in Austria, 34\% in Slovakia and a total of 82\% in Poland [see also Dogan 1998: 78-79]. In the Czech Republic, such a high percentage of people believing in a personal God cannot be found even among the age groups of people over 65 . On the other hand, one does not find a high percentage of people who do not believe in any God or life force - its only a little above one-fifth $(21.5 \%)$, while, for example, in former East Germany, this group represents more than one-half of the population $(53 \%)$. Therefore, the distribution of answers to this question could indicate a high extent of privatisation of religion in the Czech Republic, or a weakened influence of the education of believers in churches and other religious groups, where this traditional belief can be mutually strengthened.

Quite an interesting group from this point of view is comprised by the $29 \%$ of believers (according to their subjective categorisation) who do not belong to any denomination. A total of $78 \%$ of them assumed the existence of a spiritual or life force. ${ }^{6}$ These people also fail to hold other traditional (i.e. Christian) European religious dogmas. Although there are many of them who believe in the existence of God and life after death (in the first case, over $52 \%$ people said yes, in the second, over $42 \%$ of them), they usually do not believe in the existence of heaven or hell. Equally, the attendance of religious services among them is minimal, which again supports the thesis that regular church attendance is closely connected with the belief in a personal God and with other traditional Christian beliefs [Dobbelaere 1993: 21].

${ }^{6}$ ) Only one respondent from this group of 223 people expressed an opinion on the existence of a personal God; $13 \%$ did not know what to think, and $6.4 \%$ did not believe in any divine, spiritual or life force. 
Thus, we come to the question of how strong these traditional Christian dogmas in the entire set of respondents are, or how strong they could be (as a result) in the Czech population. For this purpose, we constructed an index of Christian orthodoxy (using the questions about the belief in God, life after death, hell, heaven and sin [see Halman et al. 1999: 148]) that has values from 0 to 1 , from the absence of faith in any of these items up to belief in all five of them. We discovered that the mean of this index is 0.288 , which makes the Czech Republic the second least orthodox country in Europe (just after former East Germany with the value 0.172). Just for illustration, in the Netherlands the mean value of this index is 0.382, in Austria 0.488, in Slovakia 0.563 and in Poland 0.756. However, one can get a better image from the following table (Table 5), which presents the successive categories of the constructed orthodoxy index in selected countries.

Table 5. Index of Christian Orthodoxy: Percentage of people in successive categories

(zero: belief in 0 items, very weak: belief in 1 item, weak: belief in 2

items, medium: belief in 3 items, strong: belief in 4 items, very strong: belief in all 5 items)

\begin{tabular}{lrcrrrr} 
& zero & very weak & weak & medium & strong & very strong \\
\hline Czech Republic & 37.2 & 25.4 & 15.6 & 8.7 & 4.2 & 8.9 \\
Germany (former East) & 58.5 & 12.6 & 5.4 & 3.1 & 1.2 & 7.7 \\
Germany (former West) & 16.4 & 15.7 & 13.8 & 8.9 & 5.7 & 15.2 \\
Netherlands & 27.6 & 21.1 & 17.4 & 11.7 & 11.1 & 11.2 \\
Austria & 11.8 & 22.1 & 19.7 & 17.2 & 15.2 & 14.0 \\
Slovakia & 17.3 & 13.2 & 16.4 & 11.2 & 7.9 & 34.0 \\
Poland & 2.7 & 9.0 & 13.3 & 10.1 & 12.3 & 52.6 \\
\hline
\end{tabular}

Source: $\quad$ EVS 1999.

Of course, a different level of orthodoxy will be found in the groups of people who claimed to belong to some of the Christian denominations - the mean value in the group of Czech Christians is 0.536 , and a high percentage of them falls into categories of strong or very strong orthodoxy (almost 33\% together). However, the ratio of the orthodox believers among Czech Christians is still lower than, for instance, among the whole population of Poland. The belief in some of the offered dogmas is rather low. Czech Christians usually believe in the existence of $\sin (78.5 \%$ of them) and God $(73.3 \%)$, while the rest of the beliefs - in life after death $(47.4 \%)$, in heaven (40.6\%), or even hell (28\% only) - are not held by a majority of them any more.

\section{Structural Differentiation}

The basic structural trend of religious life in modern society is the process of structural differentiation, which also includes the decreasing importance of a firm denominational tie to big traditional religious organisations typified by churches. The consequences of this process are reflected both in the individual lives of citizens and in the life of society as a whole.

Individual citizens no longer feel a strong necessity to be tied to a church (of any religious traditions) and to participate in its activities. According to the 1999 EVS survey, only $2.8 \%$ of people performed some unpaid work for a church. The frequency of attendance at religious services can also serve as an illustration of the above-mentioned trend - 
only $6.8 \%$ of people visit church at least once a week; $4.7 \%$ once a month; $13.2 \%$ several times a year, usually on the occasion of some religious holiday; $9.1 \%$ go once a year; and a total of $56.9 \%$ claim that they never visit religious services (the question excluded the occasions of weddings, burials, etc. when people go to church more out of family reasons). In comparison with 1991, there has been a slight decrease in the frequency of attendance (see Table 6).

Table 6. Attendance of religious services (in \%)

\begin{tabular}{lrr} 
& 1991 & 1999 \\
\hline more than once a week & 2.1 & 1.8 \\
once a week & 6.3 & 5.0 \\
once a month & 3.4 & 4.7 \\
Christmas/Easter day & 13.3 & 10.6 \\
on other specific holidays & 4.0 & 2.6 \\
once a year & 6.3 & 9.1 \\
less often & 11.3 & 8.0 \\
never, practically never & 53.2 & 56.9 \\
\hline
\end{tabular}

Source: $\quad$ EVS 1991 and EVS 1999.

Thus, among those who attend religious services are predominantly people who visit church only on the occasion of some holiday or perhaps to secularise important passages in life, such as marriage, birth, death, etc. However, when people had to express how important they regard religious services on these mentioned occasions, they claimed them less important than in the year 1991. Today, the religious service at birth is important for $38.2 \%$ (in 1991 it was $44 \%$ ), at marriage for $37.2 \%$ (in 1999 it was $45.9 \%$ ), and at death for $46 \%$ of people (in 1991 it was $51.7 \%$ ).

The process of structural differentiation (or secularisation) is clearly manifested in the opposition of citizens towards church influence over political or economic life. Only $5.9 \%$ of people agree with the opinion that a politician who does not believe in God is not suitable for public office, and only $8.5 \%$ think that it would be better for the Czech Republic if more religious persons held public offices. An absolute majority of citizens agree with the statement that churches should not influence voting behaviour (78.3\%) or the decisions of the government $(71.3 \%)$. At the same time, over $51 \%$ of people think that churches have influence over contemporary political life.

Churches are being pushed out of public and political life into the sphere of charity. To illustrate this, let us point to the fact that while $69 \%$ of Czech citizens in 1999 regarded the existence of churches to be necessary or useful for the care of old and sick people (in 1993 it was 78\%), only 37\% of them (or 47\% in 1993) thought that they are necessary or useful in accomplishing the good education of children (data from IVVM surveys). These data are of a high explanatory value, since the care of the old or the sick (who represent groups of 'inferior' individuals from the point of view of an economically oriented society) does not take place in households (i.e. the intimate sphere of everyday life), but is delegated to special institutions.

Other indicators of the decreasing social importance of churches are the opinions of citizens related to the church property. We can gain a good picture if we compare the opinions of people on financial self-dependence of churches with the opinion on the return of church property. According to the IVVM survey in 1997, a total of $48 \%$ of Czech 
citizens were convinced of the fact that churches should be financially self-reliant (one year before, this opinion was held by $52 \%$ of people), while only $8 \%$ of people would agree with returning all of the property that the churches owned in the time of the First Republic (i.e. before World War II), and 19\% of them would agree with returning the property held by churches before 1948 . Further, $25 \%$ of people would return only something, and $35 \%$ were convinced that churches should not be returned anything at all. At the same time, the last opinion is not held only among non-believers - every sixth believer also expressed the opinion that nothing should be returned, as well as an entire onethird of people who were not believers but conceded the existence of God.

Therefore, if citizens do not incline towards the restitution of church property, but at the same time want churches to be financially self-sufficient (and all this with the absence of any tax advantages for churches), then there might exist an unwillingness to concede bigger economic influence to religious organisations. Only 3\% of people think that churches should be totally financed by the state, and a further $35 \%$ agree with the opinion that state financing should represent a certain part. However, those who agree with state support want it to be used for charity purposes (25\%), or for the renewal (21\%), or for the upkeep (21\%) of existing church buildings and other monuments.

There is an obvious conclusion to be made from the mentioned trends - people would not like to see rich and influential churches, but they would leave to them all the care of the old, the sick or the poor (or the care of cultural heritage).

\section{Summary}

The data gained in EVS (and in other mentioned surveys) document the scope and nature of the secularisation of Czech society. At a structural level, it can be supported by presenting the opinions of respondents concerning the separation of religion (or better, churches) from the spheres of political and economic life in the Czech Republic. These views are accompanied by a relatively low level of trust in church institutions (only $20 \%$ approximately), by the belief that churches do not deal with social or family problems, and by a low frequency of attendance at religious services. Hand in hand with the decrease in the social significance of institutionalised forms of religion, or the decrease in the social importance of churches and other plausibility structures, comes a decrease of their social control over the forms of faith. The consequence of this is a privatisation of religion, also manifested by the deviance from traditional forms of belief - which can be clearly observed in the decrease of belief in a personal God [cf. Dobbelaere 1995]. Similar conclusions can also be found in other studies [i.e. results from ISSP 1998, see Hamploví 2000].

The significance of these findings deepens with an international comparison. It can be stated that in all indicators of religiousness (such as the orthodoxy index, frequency of attendance at religious services, ratio of believers, etc.), the Czech Republic shows the second lowest or even the lowest scores (Tables 5 and 7). The image of the Czech Republic as the most secularised country in Europe can be mostly confirmed (when the region of former East Germany no longer counts as a separate state). 
Table 7. Comparison of several indicators of religiousness among selected countries (in \%)

\begin{tabular}{|c|c|c|c|c|}
\hline & & people with & Atter & $\begin{array}{l}\text { nding religious } \\
\text { ervices at least }\end{array}$ \\
\hline & believers & denomination & believers in God & once a week \\
\hline Czech Republic & 40.4 & 33.5 & 33.1 & 6.8 \\
\hline Germany (former East) & 27.6 & 33.9 & 30.2 & 5.8 \\
\hline Germany (former West) & 58 & 85.6 & 69 & 15.8 \\
\hline Netherlands & 60.7 & 44.9 & 58.0 & 13.9 \\
\hline Austria & 75.0 & 87.0 & 82.7 & 22.7 \\
\hline Slovakia & 76.7 & 76.8 & 75.9 & 40.5 \\
\hline Poland & 91.8 & 95.7 & 96.2 & 58.7 \\
\hline
\end{tabular}

Source: $\quad$ EVS 1999.

This fact can to a large degree be explained by the historic development of the Czech state. It should be noted that in other post-communist countries (with the exception of former East Germany) such dramatic declines in the social significance of religion did not occur. We can assume that our history created the hidden potential for secularisation (which need not be a specific feature of the Czech Republic) which fully materialised only in the atmosphere of state atheism. The data from the earlier censuses conducted in this century document that there had been a high and relatively stable number of believers/church members in years 1921 (92.82\%), 1930 (92.19\%) and even in 1950 (93.9\%), and only a low percentage of people without denomination. However, the data from 1991 show a completely different picture of religiousness $-43.91 \%$ of believers and $39.92 \%$ of people without denomination [see Náboženské... 1995].

The analysis of quantitative data from EVS and other surveys has revealed the need for further quantitative and qualitative research of religion in the Czech Republic which would focus on the non-institutionalised diffuse religiousness of a privatised type (both within the traditional forms of religions, as well as in connection with the emergence and existence of new religious movements, which have a low statistical significance but a high social impact). It is also necessary to verify some methodologically important aspects of the research of religion under the specific conditions of the Czech Republic, such as varying connotations of the terms 'religion', 'religious person', 'religious belief', 'believer', etc. This clarification would be useful for further adequate use of standardised questionnaire forms within the international research of religion and religious values.

DUŠAN LUŽNÝ studied sociology at the university in Brno. At the present time, he works and teaches at the Institute for the Study of Religions at the Faculty of Arts of Masaryk University in Brno. He focuses on the issues connected with the existence and activities of new religious movements and on the transformations of religion in the globalisation process. He is the author of monographs Nová náboženská hnutí [New Religious Movements] (1997), Náboženství a moderní společnost: sociologické teorie modernizace a sekularizace [Religion and Modern Society: Sociological Theories of Modernisation and Secularisation] (1999) and Zelení bódhisattvové: sociálně a ekologicky angažovaný buddhismus [The Green Boddhisattvas: Socially and Ecologically Engaged Buddhism] (2000).

JOLANA NAVRÁTILOVÁ graduated in English and sociology at Masaryk University in Brno and at present she studies in the doctoral programme of sociology at the School of Social Studies of 
this university. She is working on a thesis on Cyberfeminism, and apart from feminism, she is interested in cyberculture, environmental movements and other minority subcultures.

\section{References}

Berger, P. 1967. The Sacred Canopy: Elements of a Sociological Theory of Religion. New York: Doubleday.

Dobbelaere, K. 1993. "Church Involvement and Secularization: Making Sense of the European Case” Pp. 19-36 in Secularization, Rationalism and Sectarianism, ed. by E. Baker, J. Beckford and K. Dobbelaere. Oxford: Clarendon Press.

Dobbelaere, K. 1995. "Religion in Europe and North America." Pp. 1-29 in Values in Western Societies, ed. by R. de Moor. Tilburg University Press.

Dogan, M. 1998. "The Decline of Traditional Values in Western Europe. Religion, Nationalism, Authority". International Journal of Contemporary Sociology, no. 1: 77-90.

Halman, L., T. Petterson, J. Verweij 1999. "The Religious Factor in Contemporary Society: The Differential Impact of Religion on the Private and Public Sphere in Comparative Perspective." International Journal of Contemporary Sociology, no. 1: 141-160,

Hammond, P., M. Shibley 1993. "When the Sacred Returns: An Empirical Test." Pp. 37-46 in Secularization, Rationalism and Sectarianism, ed. by E. Baker, J. Beckford and K. Dobbelaere. Oxford: Clarendon Press.

Hamplová, D. 2000. “Šetření ISSP 1998 - Náboženství [International Social Survey Program 1998 - Religion].” Sociologický časopis 36(4): 431-440.

Luckmann, T. 1967. The Invisible Religion: The Problem of Religion in Modern Society. New York: Macmillan.

Náboženské vyznání obyvatelstva podle výsledků sčitání lidu v letech 1921-1991 [Religious Denomination of the Population According to the Census Results in 1921-1991] 1995. Praha: Český statistický úřad.

Spousta, J. 1999. "Církve očima sociologických výzkumů [Churches through the Eyes of Sociological Research].” Pp. 73-90 in Náboženství v době společenských změn [Religion in a Period of Social Changes], ed. by J. Hanuš. Brno: Masarykova Univerzita.

Stark, R., W. S. Bainbridge 1996. A Theory of Religion, 2nd edition. New Brunswick: Rutgers University Press.

Štampach, O. 1999. "Náboženské spektrum České republiky [The Religious Spectrum of the Czech Republic].” Pp. 53-72 in Náboženství v době společenských změn [Religion in a Period of Social Changes], ed. by J. Hanuš. Brno: Masarykova Univerzita.

Tomka, M. 1988. "Tendencies of Religious Change in Hungary." Archives de Sciences sociales des Religions 65(1): 67-79.

Wilson, B. 1979. "The Return of the Sacred." Journal for the Scientific Study of Religion 18: 268280.

Wilson, B. 1992. Religion in Sociological Perspective, 6th edition. Oxford, New York: Oxford University Press. 